\title{
Investment Perspectives in Human Resources Management and Its Contribution on Organizational Performance and Competitive Advantages
}

\author{
Moh. Roziq ${ }^{1}$, Harry Putri Reawaroe ${ }^{2}$; Achmad Imron Rosyidi ${ }^{3}$ \\ TANRI ABENG UNIVERSITY 1 \\ BUDI LUHUR UNIVERSITY-'MAGISTER MANAGEMENT, ,2,3 \\ Email: muhammad.roziq@tau.ac.id; harryputri03@gmail.com; aimronr@gmail.com \\ Received: January $6^{\text {th }} 2021$ \\ Approved: March 15 2021

\begin{abstract}
The dynamics of business environment signed by the volatility, uncertainty, complexity and ambiguity (VUCA) is urging organizations to rethink and redefine their business strategies and the source of their performance and competitive advantage. Human resources (human capital) hold the most important role in achieving organizational goals through the alignment of human capital investment and the organizational strategy. This article investigates on how the organization manage and align the investment in human resources (human capital) with the strategy of the organization and does investment in human capital have impact to the organizational performance and contribute to the creating value and competitive advantages of the organization. Based on the literature reviews and previous researches, we found that the alignment of investment in human resource (human capital) and organizational strategy is mediated by strategic performance management system namely Balanced Scorecard. The investment in human resources (human capital) has positive impact on organizational performance. Finally, The investment in human resources (human capital) has positive contribution to value creation and competitive advantages of the organizations.
\end{abstract}

Key Words: Investment Perspective in Human Resource Management (Human Capital); Strategic Performance Management System - Balanced Scorecard; Organizational Performance; and Competitive Advantages 


\section{Introduction}

The dynamics of business environment signed by the volatility, uncertainty, complexity and ambiguity (VUCA) is urging organizations to rethink and redefine their business strategies and the source of their competitive advantage. In today's knowledge economy, understanding the potential of organization's resources and optimizing the output of such resources provide an opportunity for the Human Resource Management (HRM) function to become a key source for adding value and creating a competitive advantage to the organization (Afiouni, 2009). Many organizations nowadays derive their competitive advantage from their human resources/human capital, and it becomes critical for organizations to select human capital that matches their strategic goals. Human capital (HC) must be identified, and maintained, and it should be treated as investments instead of expenses in accounting records and terms (AlGhazawi, 2012).

\section{Literature Review}

The term of human capital was originated by Schultz (1961). Human capital, as a concept, is thus anchored in economics rather than management theory. Currently, there are a variety of definitions and ideas associated with the human capital concept in a variety of disciplines including economics, accounting, human resource management (HRM), and intellectual capital. However, despite the trendy use of the term human capital among business practitioners and consultants, the human capital literature remains fragmented with studies differing in the conceptualization of human capital (Unger et al., 2011) According to Bontis and Fitz-enz, (2002), human capital is the sum of knowledge, skills, experience and other relevant workforce attributes that reside in an organization's workforce and drive productivity, performance and the achievement of strategic goals. They added that human capital is the combined knowledge, skill, innovativeness and ability of the company's individual employees to meet the task at hand.

Human capital management is an old discipline to the financial and investment analysts as well as to the accountants and human resources professionals. As defined by Baron \& Armstrong (2007), human capital management is concerned with obtaining, analyzing and reporting on data which informs the direction of value-adding people management strategic, investment and operational decisions at corporate level and at the level of front-line 
management. It requires a new set of skills, which is not available in the market but has to be created; hence it is a challenging discipline, demanded by most of the organizations to increase the return on investment. HCM is a system approach to people management. HCM is the discipline of acquiring, retaining, measuring, managing, and leveraging the workforce. In short, it's about treating employees as an asset rather than mere overhead - helping them understand their own effectiveness on the job.

In human resources management research and practice, human capital management has attracted an increasing interest over the last 15 years from the human resources profession, media, and consultancy firms. The concept of investing in the human capital has been the source of attention in the management society. Investing in the human capital is a process of spending time, money and efforts on developing the skills and talents of the individual in a way that encourages him to double their productivity. Investing in the human capital can be considered as the information, skills, knowledge, talents, performance tools and attitudes that an individual collects through organized learning which helps in improving the quality to the performance outcomes which in its turn improves the quality of the work.

Human Capital is increasingly believed to play an important role in the growth process, so the attention headed towards the investment in Human Capital. This concept is relatively varying from one organization to another (Al-Adwani, 2014). The importance of human capital as a source of progress and economic growth has long been recognized in the literature of economics. In the economic perspective, the capital refers to factors of production used to create goods or services. The human is the subject to take charge of all economic activities such as production, consumption, and transaction. Thus, it can be recognized that human capital means one of production's factors, which can generate added values of the organization. Human capital could be defined as the knowledge, skills, abilities and capabilities possessed by people General human capital is defined as generic knowledge and skill, not specific to a task or a company, usually accumulated through working experience and education (Al-Ghazawi, 2012).

Mello (2015) in his book, heightened attention to be shown and greater appreciation paid toward the value of strategic human resource management in organizations. Boards of Directors, business owners, stockholders and senior executives are gaining a greater understanding of the relationship between HR and organizational, market and financial performance as cutting-edge research illustrates the connection between HR practices and firm performance. 
Skills, experience and knowledge have economic value to organizations because they enable it to be productive and adaptable; thus people constitute the organization's human capital. Like other assets, human capital has value in the market place, but unlike other assets, the potential value of human capital can be fully realized only with the co-operation of the person. Therefore, all costs related to eliciting productive behaviors from employees including those relating to motivating, monitoring and retaining them - constitute human capital investments made in anticipation of future returns.

Performance of human capital is currently evaluated in terms of creativity, innovation, quality and flexibility. Thus, the role of people (human resources) is being redefined when it contributes to value creation. An increasing number of organizations are realizing that HR managers have a strategic role in designing and implementing HR policies, systems and practices that will develop the firm's human capital and boost its performance. This article investigates on how the organization manage and align the investment in human resources (human capital) with the strategy of the organization and does investment in human capital have impact to the organizational performance and contribute to the creating value and competitive advantages of the organization.

\section{Methodology}

Investing in human assets leads to a dilemma for management and organization. An organization that does not invest in its employees may be less attractive to prospective employees and may have a more difficult time retaining current employees; this causes inefficiency (downtime to recruit, hire, and train new employees) and a weakening of the organization's competitive position. However, an organization that does invest in its people needs to ensure that these investments are not lost. In the other side, well-trained employees, for example, become more attractive in the marketplace, particularly to competitors who may be able to pay the employee more because they have not had to invest in the training that the employee has already received.

Investment in human capital considered as a risky investment to take. Consequently, organizations need to develop strategies to ensure that employees stay on long enough for the organization to realize an acceptable return on its investment relative to the employees' acquired skills and knowledge, particularly when the organization has subsidized the acquisition. This requires the organization to determine the actual "value" of each employee. 
Valuation of human assets has implications for compensation, advancement opportunities, and retention strategies as well as how much should be invested in each area for each employee.

Moreover, the human capital management framework is well supported by the work of Becker and Huselid (2006) which discuss the challenges facing Strategic Human Resources Management (SHRM) and the new directions in SHRM research and practice. They argue that strategy implementation is the mediating factor between human resource and firm performance, and consider strategy to be a source of building sustainable competitive advantage. According to them, it is the fit between the 'human resources architecture' (composed of the systems, practices, competencies, and employee performance) and the firm's strategy that is the foundation of human resource's impact on the firm's performance and its contribution to the firm's competitive advantage. This idea is well echoed in the proposed human capital management framework.

In this article, the research problems are defined as follows:

1. How does the organization manage and align the investment in human capital with the strategy of the organization?

2. Does investment in human capital have impact to the organizational performance?

3. Does investment in human capital contribute to the creating value and competitive advantages of the organization?

To answer this research problem, the literature review is conducted by summarizing and interpreting several articles or publication related to the topic. The qualitative research analysis (interpretive) was conducted to interpret the phenomena or previous research findings. The topics was focused on: 1). Managing and Aligning Human Capital Investment into Organization's Strategy; 2). Human Capital Investment: Its Impact on Organizational Performance; and 3). Human Capital Investment: Its Contribution to Value Creation \& Competitive Advantage.

\section{Result}

\section{Managing and Aligning Human Capital Investment in to Organization Strategy}

Managing an organization's employees as investments mandates the development of an appropriate and integrated approach to managing human resources that is consistent with the organization's strategy. As an example, consider an organization whose primary strategic objective involves innovation. An organization pursuing an innovation strategy cannot afford 
high levels of turnover within its ranks. It needs to retain employees and transfer among employees the new knowledge being developed in-house. It cannot afford to have its employees develop innovative products, services, and processes and then take this knowledge to a competitor for implementation.

The ultimate purpose of the strategy is to drive enterprise performance. One strategy is implementing BSC which draws a balance between financial, operational, and non-financial aspects consisting of financial, customer, internal business process, and learning and growth perspectives. The balanced scorecard (BSC) overcomes the limitations of the traditional system measures by complementing financial measures of past performance with the measures of future drivers performance (Al-Najjar and Kalaf, 2012). Balanced scorecard (BSC), originally developed by Kaplan and Norton (1992), is known as a management tool for strategic performance. It consists of financial, customers, internal business process, and learning and growth perspectives. It is argued that the BSC approach is very much depends on the organization's or corporation's needs. BSC forces managers to also focus on nonfinancial perspectives which affect organization's long-term profitability, rather than its financial perspectives (Abofaied, 2017).

The interest in BSC has grown tremendously among academicians and practitioners since 1996. The most significant role of BSC is its ability to translate the corporate's mission and strategy into measurable and tangible objectives by focusing on the most meaningful and important measures. BSC is one of the most popular management systems which clarify and translate the organization's vision and strategy into actions. Therefore, BSC enables executives to accomplish the corporate's vision and strategy effectively.

Doving \& Nordhaugh (2010) study drivers of firms' human resource planning practices. This is done by analyzing two central parts of personnel planning, formal HRM strategies and analyses of competence development needs. Results indicate that resources (size, having an HRM department and corporate affiliation) and to some degree cost-benefit considerations are the main determinants of these human resource planning arrangements. Moreover, institutional factors have an impact on firms' use of competence needs analyses.

\section{Human Capital Investment: Its Impact on Organizational Performance}

Hanson et al (2004) suggests that investments in training generate substantial gains for firms even if employees can use this training in other firms. The evidence that employers profit from training investments comes from different countries including Britain, France, Ireland, 
the Netherlands, Sweden, and the US. Most of these studies indicate that training affects performance and not the other way around. The effects of education and skills/competence on aspects such as productivity and innovations are generally found to be positive and significant, though the connection with profitability might be less expected. Firms can also extract profit from prior education as they do from general training investments. Supporting employee development through training policies and methods for analyzing training needs is important to explain the provision of training and training outcomes. Similarly, innovative (and comprehensive) HRM practices tend to be associated with positive company performance. Innovation and information technology (IT) both result in greater investment in training and also depend on education and skills in generating profits. Other findings suggest that training and comprehensive HRM.

Al-Adwani (2014) proved that investment in human capital through training the new employees as well as training the trainers has positive significant effects on performance, productivity and the overall success. The performance of human capital is being observed using the Balanced Scorecard as a management system strategy. Finally the researcher presented some recommendations as the following: while involving the employees in decision making process the managers must be aware about the privacy of some decisions regarding its importance and how much it is dangerous to be spread outside the organization. In addition of that the researcher recommends to integrate the modern concepts of balanced scorecard in order to achieve better measurements and estimation for human capital.

Bae \& Patterson (2014) analyze the effect of Korean firms' human capital investment on their employees' performance, and to seek ways to strategically utilize it. A major Korean financial corporation was selected and its data related to personnel affairs and education was analyzed to determine the effects of school education, job training, job experience, language ability, and certification on employee's performance. According to the result, school education generally has a positive effect. Job training has showed different effect on employees' performance and in particular it had little effect on employees' performance in job families requiring an advanced academic degree.

Huaming \& Hang (2016) conclude that the performance of enterprises positively correlates to the human capital investment. Meanwhile, the study shows that the increase of the human capital investment is beneficial to increasing the level of human capital of the whole society. The study shows practical significance of researching the human capital investment of enterprises. 
Numerous studies linking the human capital and organizational performance abound. For the long-term survival and sustainability of the organization, firm will need to invest resources to ensure that employees have the knowledge, skills and competencies they need to work effectively in a rapidly changing and complex environment (Marimuthu, Arokiasamy and Ismail, 2009). Results from most studies showed positive relationship between human capital investment on performance (Mabey and Ramirez, 2005); thus Katou (2009) reported that there is a large and growing body of evidence that demonstrates a positive linkage between the development of human capital and organizational performance. The results of this study provide some useful insights and information on the effect of investment on human capital on both the financial and non-financial performance. It has been found that the four popular variables i.e., skills, education, knowledge and training determine the human capital effectiveness and are also good predictors of human capital effectiveness. Training and skills are found to be stronger predictors of human capital effectiveness, though there is high inter correlation among the four variable measures. The study revealed a strong relationship between human capital effectiveness and financial performance and a strong relationship between human capital effectiveness and non-financial performance.

In successful companies, there are major investments on staff in order to increase and improve insight, abilities and experiments to compete in today's changeable environment (Wang et al., 2011). Experiments have showed that increment of staff abilities and capabilities directly affects financial outcome of a company (Doong et al., 2011). Boheme (2011) studied effects of skills of human resources management on performance. One thousand (1000) employees were used as simple sampling and the result indicated that there is a strong positive relation between employment, selection and performance.

\section{Human Capital Investment: Its Contribution to Value Creation \& Competitive Advantage}

The Resource-based View (RBV) suggests that a firm can secure a sustained competitive advantage through facilitating the development of competencies that are firm specific, produce complex social relationships, are embedded in a firm's history and culture, and generate tacit organizational knowledge (Barney, 1991).

Economic value Added (EVA) is a financial performance method to calculate the true economic profit of an organization. It shows how much true profit is left only after paying all expenses, including taxes, but also after subtracting the cost of invested capital. It is defined as net operating profit after tax minus the cost of capital. EVA can be given a human capital 
perspective by dividing it by the average headcount within the calculation period. So, the formula can be re-stated as; HEVA= (net operating profit after tax-cost of capital)/Average headcount. Another simple method described by PWC Saratoga Institute, naming HEVA as wealth created per employee.

\section{HEVA= (Net operating profit after tax - 10\% shareholder's equity $) /$ Average Headcount.}

Value added is the difference between the cost of materials and labor to produce a product and the sale price of a product. HCVA generates an adjusted profitability figure by each employee in the organization. PWC Saratoga Institute suggests calculating HCVA by subtracting all corporate expenses except for pay and benefits from Revenue and dividing the adjusted profit by the average headcount.

\section{HCVA= Revenue- $($ Total Costs - Employment cost $) /$ Average headcount .}

As total cost item is not mentioned in none of the financial statements, it is defined as the difference between the Revenue and Profit Before Taxes.

Another relationship of human capital investments to profitability can be made visible through a ratio that follows from the formula for HCVA. HCROI looks at the ROI in terms of profit for monies spent on human capital employment costs. It drives human capital practitioners to the conclusion that they can have as direct an impact upon revenue and nonpeople related costs as any other business partner. HCROI represents the leverage of human capital employment cost within an organization.

\section{HCROI= $($ Operating Cost + Employment Cost $) /$ Employment Cost}

The human capital management framework provides practitioners with an action plan to link their managerial actions with both employee and organizational outcomes. It proposes that companies need the right managerial behaviors as well as the right organizational infrastructure and vision in order to create a competitive advantage through people. Moreover, in line with the work of Santos-Rodrigues et al. (2010), the human capital management framework shows that competitive advantage can be created through people, if managers link their action plans to their employees and organizational outcomes. In fact, a group of highly motivated and capable employees represents a firm-specific, rare, and inimitable resource and ingredient of competitive advantage. It is the managers' responsibility to encourage their employees and motivate them to manage their knowledge 
and capacities in a way that is in line with the firm's objectives to contribute to organizational gains (Santos-Rodrigues et al., 2010). In term of sustainability, Kucharcikova et al (2018) proposed example of HCM implementation in the part of evaluating the effectiveness of investment in education and the article can serve as a theoretical and practical aid to human resources managers in implementing the HCM concept.

\section{Discussion}

Giziene et al (2012) suggested that the investment in human capital is a complex problem from both practical and scientific aspect, so the practice of such evaluation and applied methods do not give an unambiguous answer. It is very important to evaluate the effectiveness of this investment, to estimate the detention of the time, the money flows: incomes (revenues) and outcomes (expenditures). Gumperz (2014) also suggest the importance on financial analysis and investment return consideration in investing human resources.

The relevance of the questions dealing with the human capital formation and functioning peculiarities in the innovative development conditions is provided by the fact that highly developed post-industrial economy, manufacturing and service sector cannot do without highly educated and skilled workers, that makes dependable the efficiency and competitiveness at the company level and the whole national economy Forrester et al (2016). Garcia-Alcaraz et al (2018) presents a structural equations model to identify the relationships between managerial commitment, Six Sigma implementation strategy, investments in human resources and the economic benefits obtained. The results indicate that managerial commitment is the basis for Six Sigma success, but requires an adequate implementation strategy focused on customers and their needs, which must integrate an investment plan in human resources that is focused on training and teamwork. In addition, managers must have a reward program that encourages motivation and recognizes the achievements of the human resources involved.

\section{Conclusion and Recommendation}

Based on the analysis and discussion from previous researches and literature reviews, the conclusion can be summarized below:

1. Those executives that are taking up the challenge should be more involved in human capital management to carve out a role in integration of HR policy and corporate strategy, 
and in the development of new metrics. The executives are grappling with the challenge of measuring the return on investments on employees' investments and understanding in greater detail how the human capital generates value for the business.

2. For many companies, human capital represents a neglected area of opportunity. If it is indeed an essential factor in an organization's ability to innovate and grow profitably, then human capital is something executives can no longer afford to take for granted. Although it is not yet clear what approaches will yield the greatest return. At least, they may discover how dependent their companies are on this intangible source of value for success.

3. Human capital has a critical role in these turbulent times of global economy where effective organization management, productivity, efficiency and performance have critical role. So do talent. Showing the employee performance added value per employee are important more than ever. Human capital manager should excel on measurement and increase the ability of creating many other performance related metrics and should come up with external benchmark data. That is how human capital will be treated as strategic business partner and adds value to sustainable competitive advantage.

This article is based on literature review and previous researches focus on investment in human resources (human capital) and its impact on organizational performance and its contribution to value creation and competitive advantages of the organization. The future researches have to measure the impact of investment in human capital towards organizational performance and its contribution to value added and competitive advantage of organization using the appropriate data.

In relation with the organizational performance, the future research suggested to explore as to which indicator leads to higher performance and why? The future studies may validate the relations for other industries both in public and social sectors. The future researcher may go for an objective organizational performance measures.

In relation with the competitive advantages, the future research suggested to addresses some important questions with regards to human resource training such as: Which training methods and topics are most important for learning by doing? How the product of training is transformed into tacit knowledge and how is it integrated into the broader problem-solving activities in the firm? Future research seek to develop deeper insights into the workings of social complexity and time compression diseconomies and the role they play in protecting human capital from imitation. 


\section{References:}

Abofaied, A. (2017). Evaluation of Bank's Performance By Using Balanced Score Card: Practical Study in Libyan Environment. International Journal of Business and Management, $V(1), 1-14$.

Afiouni, F. (2009). Leveraging Human Capital and Value Creation by Combining HRM and KM Initiatives. International Journal of Learning and Intellectual Capital, 6(3), 202213.

Afiouni, F. (2013). Human Capital Management: A New Name for HRM? International Journal of Learning and Intellectual Capital, 10(1), 18-34.

Al-Adwani, A. B. (2014). The Extent to Which Human Resources Managers in KNPC Believe in Human Resource Investment. International Business Research, 7(4), 132141.

Al-Ghazawi, M. (2012). The Impact of Investments in Human Resources Activities on the Effectiveness of Investment in Human Capital: The Case of Commercial Banks in Jordan. International Journal of Business and Social Science, 3(18), 253-261.

Al-Najjar, S. M., \& Kalaf, K. H. (2012). Designing a Balanced Scorecard to Measure a Bank's Performance: A Case Study. International Journal of Business Administration, 3(4), 44-53.

Bae, S. O., \& Patterson, L. (2014). The Effect of Corporate Investment in Human Capital on Employee's Performance: Major Korean Financial Corporation Examined. Electronic Business Journal, 13(1), 1-22.

Barney, J. (1991). Firm Resources and Sustained Competitive Advantage, Journal of Management, Vol. 17, No. 1, pp.99-120.

Barney, J. and Wright, P.M. (1998). On Becoming a Strategic Partner: the Role of Human Resources in Gaining Competitive Advantage, Human Resource Management, Vol. 37, No. 1, pp.31-46.

Baron, A. and Armstrong, M. (2007) Human Capital Management, Kogan Page Limited, London and Philadelphia.

Becker, B. and Gerhart, B. (1996). The Impact of Human Resource Management on Organizational Performance: Progress and Prospects', Academy of Management Journal, Vol. 39, No. 4, pp.779-801.

Becker, B.E. and Huselid, M.A. (2006). Strategic Human Resources Management: Where do We Go from here?, Journal of Management, Vol. 32, No. 6, pp.898-925.

Becker, R. W., \& Collins, R. A. (2013). Human Capital Investment. Human Capital Investment for Central City Revitalization, 1-11.

Bontis, N. \& Fitz-enz, J. (2002), Intellectual Capital ROI: A Causal Map of Human Capital Antecedents and Consequents, Journal of Intellectual Capital, Vol. 3 No. 3, pp. 223247.

Døving, E., \& Nordhaug, O. (2010). Investing in Human Resource Planning: An International Study. Management Revu, 21(3), 292-307.

Forrester, S. V., Ustinova, G. H., Kosyakova, I. V., Ronzhina, N. V., \& Suraeva, M. O. (2016). Human Capital in the Innovative Conditions. IEJME - Mathematics Education, 11(8), 3048-3065. 
García-Alcaraz, J. L., Alor-Hernández, G., Sánchez-Ramírez, C., Jiménez-Macías, E., Blanco-Fernández, J., \& Latorre-Biel, J. I. (2018). Mediating role of the six sigma implementation strategy and investment in human resources in economic success and sustainability. Sustainability (Switzerland), 10(6).

Giziene, V., Simanaviciene, Z., \& Palekiene, O. (2012). Evaluation of Investment in Human Capital Economical Effectiveness. Engineering Economics, 23(2), 106-116.

Gumperz, J. (2014). Investment in Human Resources and the Evaluation of Capital. Financial Analist Journal, 20(5), 134-135.

Hansson, B., Johanson, U., \& Leitner, K.-H. (2004). The Impact of Human Capital and Human Capital Investments on Company Performance. Evidence from Literature and European Survey Results. Cedefop Reference Series 54, (30), 261-319.

Huaming, W., \& Hang, J. (2016). An Empirical Study on the Performance of Enterprises and Investment in the Human Capital. Proceedings - 2016 IEEE 1st International Conference on Data Science in Cyberspace, DSC 2016, 497-502.

Kaplan R. S, Norton D. P (1992) The Balanced Scorecard - Measures that Drive Performance. Harvard Business Review 70: 71-79.

Kaplan R. S, Norton D. P (1996) Using the Balanced Scorecard as a Strategic Management System. Harvard Business Review 79: 75-85.

Kucharčíková, A., Mičiak, M., \& Hitka, M. (2018). Evaluating the Effectiveness of Investment in Human Capital in E-business Enterprise in the Context of Sustainability. Sustainability (Switzerland), 10(3211).

Li, Q., Qian, X., Gong, S., \& Tao, Z. (2014). Impact of Human Capital Investment on Firm Performance: An Empirical Study of Chinese Industrial Firms. Proceeding - Advances in Intelligent Systems and Computing, 109, 1269-1280.

Marimuthu M, Arokiasamy L, Ismail M. (2009). Human Capital Development and Its Impact on Firm Performance: Evidence from Developmental Economics, The Journal of International Research, Vol.2, Iss 8, pp 265-272.

Mello, J. A. (2015). Strategic Human Resource Management (Fourth Ed). Stamford - USA: CENGAGE Learning.

Ren, Y., \& Laisheng, Y. (2011). nvestment in Human Capital and Business Performance Based on Training Perspective. Proceeding - IEEE International Conference 2011, 5615-5618.

Santos-Rodrigues, H., Dorrego, P.F. and Jardon, C.F. (2010). The Influence of Human Capital on the Innovativeness of Firms, International Business and Economics Research Journal, Vol. 9, No. 9, pp.53-63.

Schultz, T. W. (1961). Investment in Human Capital. The American Economic Review, 51 (1), 1-17.

Subramony, M., Krause, N., Norton, J., \& Burns, G. N. (2008). The Relationship Between Human Resource Investments and Organizational Performance: A Firm-Level Examination of Equilibrium Theory. Journal of Applied Psychology, 93(4), 778-788.

Unger, J.M., Rauch, R., Frese, M. and Rosenbusch, N. (2011). Human Capital and Entrepreneurial Success:A Meta-analytical Review. Journal of Business Venturing, Vol. 26, No. 3, pp.341-358.

Zakharova, O., \& Kratt, O. (2014). Economic study and risk estime of the investment in the human capital. Economics and Sociology, 7(2), 94-108. https://doi.org/10.14254/2071789X.2014/7-2/8 